\title{
8. VOLATILE CONTENTS OF IZU-BONIN FOREARC VOLCANIC GLASSES ${ }^{1}$
}

\author{
Sally Newman ${ }^{2}$ and Sieger R. van der Laan ${ }^{3}$
}

\begin{abstract}
Eleven glasses recovered from Holes 786A and 786B were fresh enough for volatile analysis by infrared spectroscopy. The compositions of these glasses range from boninitic to rhyolitic. The glasses from the boninites contain 1.4 to $1.7 \mathrm{wt} \% \mathrm{H}_{2} \mathrm{O}$, while the rhyolitic glasses contain 2 to $6 \mathrm{wt} \% \mathrm{H}_{2} \mathrm{O}$, and all glasses have less than 30 to $40 \mathrm{ppm} \mathrm{CO}_{2}$. The highest $\mathrm{H}_{2} \mathrm{O}$ contents are probably the result of seawater alteration. The unaltered dacitic to rhyolitic glasses were probably quenched at low pressures corresponding to depths of $0-700 \mathrm{~m}$ below the seafloor, also corresponding to the depths of collection of these samples, although the water depths may have been different between the Eocene and the present. The lower boninitic $\mathrm{H}_{2} \mathrm{O}$ contents in vesicular glasses suggest shallow quenching on the seafloor.
\end{abstract}

\section{INTRODUCTION}

Since the resurgence of interest in boninites in the late $1970 \mathrm{~s}, \mathrm{H}_{2} \mathrm{O}$ has been recognized as crucial to the genesis of this magma type (Kuroda et al., 1978; Cameron et al., 1979). The stable isotope studies of Kyser et al. (1986) indicated that 1 to $2 \mathrm{wt} \% \mathrm{H}_{2} \mathrm{O}$ is of magmatic origin in boninites, and Dobson and O'Neil (1987) inferred that the primary magmas from Chichi-Jima, Bonin Islands, contained 1.6 to $1.7 \mathrm{wt} \% \mathrm{H}_{2} \mathrm{O}$.

With the emergence of new analytical techniques and their introduction into geochemistry, in-situ microanalysis of volatiles can now be performed. The technique of Fourier transform infrared (FTIR) spectroscopy allows us to analyze small spots of selected clear portions of unaltered glass, thus largely circumventing the problem of secondary $\mathrm{H}_{2} \mathrm{O}$ gain during alteration. We have used FTIR spectroscopy to analyze volcanic glasses from the Izu-Bonin forearc.

All samples were taken from Site 786 in the Izu-Bonin forearc where a unique sequence of boninites to rhyolites was recovered. We determined $\mathrm{H}_{2} \mathrm{O}$ and $\mathrm{CO}_{2}$ contents of glasses ranging from primitive boninites to highly evolved rhyolites, to assess the role of volatiles in the magmatic processes. The effect of water on crystallization is further discussed by van der Laan (this volume). In addition, the volatile content reflects the confining pressure at eruption, since the solubilities of volatiles are pressure dependent. This places constraints on the depth of quenching and could give insight into the volcanic processes.

\section{STRATIGRAPHY AND AGE RELATIONS OF THE BASEMENT SEQUENCE}

A detailed description of the lithostratigraphy, the petrography, and the age relationships among the cooling units formed the subject of contributions by Arculus et al., van der Laan et al., and Mitchell et al. (all in this volume). Their findings are briefly summarized here.

The $720 \mathrm{~m}$ of igneous basement (Fig. 1) is a $40-42 \mathrm{Ma}$-old volcanic construct of low-Ca bronzite andesite intrusives at the base,

${ }^{\text {I}}$ Fryer, P., Pearce, J. A., Stokking, L. B., et al., 1992. Proc. ODP, Sci. Results, 125: College Station, TX (Ocean Drilling Program).

${ }^{2}$ Division of Geological and Planetary Sciences 170-25. California Institute of Tech nology, Pasadena, CA 91125 , U.S.A.

${ }^{3}$ Hawaii Institute of Geophysics, University of Hawaii at Manoa, 2525 Correa Rd., Honolulu, HI 96822, U.S.A. overlain by a cogenetic sequence of low-Ca boninites and bronzite andesite pillow lavas. This basal sequence is cut by rhyolite dikes, and overlain by a series of predominantly intermediate-Ca bronzite andesite and andesite flows and breccias with minor dacite and rhyolite flows, all of similar age (40-42 Ma).

In a second, minor phase of igneous activity at about 34-35 Ma, intermediate- $\mathrm{Ca}$ and high-Ca boninite dikes and sills were emplaced throughout the sequence. A third intrusive event, postulated at about $17 \mathrm{Ma}$, is more speculative. It is thought to have produced the high-Ca, intermediate-Ca, and low-Ca boninite sills and dikes at the top of the sequence of Hole 786B and those of Hole 786A.

Thus all three episodes are characterized by boninite magmatic activity, but only the first episode gave rise to evolved magma compositions.

\section{SELECTION AND DESCRIPTION OF SAMPLES}

A set of 187 samples was selected for thin-section preparation from approximately $725 \mathrm{~m}$ of cored igneous basement. Ten of these samples contained glass that was sufficiently fresh to analyze using FTIR spectroscopy. The location of these ten samples in the stratigraphic sequence is indicated in Figure 1. All of our samples from Hole $786 \mathrm{~B}$, with one exception, are thought to belong to the edifice-building igneous episode and are therefore 40 to $42 \mathrm{Ma}$ old. The exception (Sample 125-786B-37R-3, 31-35 cm) is the sample forming the chilled margin of an intermediate-Ca boninite sill, which, most likely, was emplaced during the 34-35 Ma igneous event. The two samples of Hole 786A (125-786A-13X-CC and 125$786 \mathrm{~A}-14 \mathrm{X}-\mathrm{CC}$ ) could belong to either episode, or be even younger if derived from a sill (Mitchell et al., this volume), although neither of these samples has actually been dated. Note that two samples (125-786B-37R-3, 38-40 cm, and 125-786B-21R-2, 28-32 cm) are located within $8 \mathrm{~cm}$ of a dike/sill.

The cored volcanic samples generally have glassy matrices with very abundant microlites (Fig. 2 A). Some plagioclase, pyroxene, and olivine phenocrysts were observed, although phenocrysts are relatively scarce $(<5 \%)$. Only Samples 125-786B-21R-2, 28-32 cm, 125$786 \mathrm{~A}-13 \mathrm{X}-\mathrm{CC}$, and $125-786 \mathrm{~A}-14 \mathrm{X}-\mathrm{CC}$ are dominantly glass. Sample 125-786B-21R-2, 28-32 cm, contains glass of two different colors (clear and yellowish brown; Fig. 2B). Yellow coloring indicates the early stages of perlitic alteration and values obtained from glass of this color are therefore less reliable. Samples 125-786A-13X-CC and $125-786 \mathrm{~A}-14 \mathrm{X}-\mathrm{CC}$ contain fresh vesicular glass (up to $20 \%$ ) in a brecciated matrix (Fig. 2C). Sample 125-786B-37R-3, 31-35 cm contains a glassy margin that juxtaposes clear, relatively crystal-poor $(<5 \%)$ and dark-brown, crystal-rich ( $>30 \%)$ glasses (Fig. 2D). 


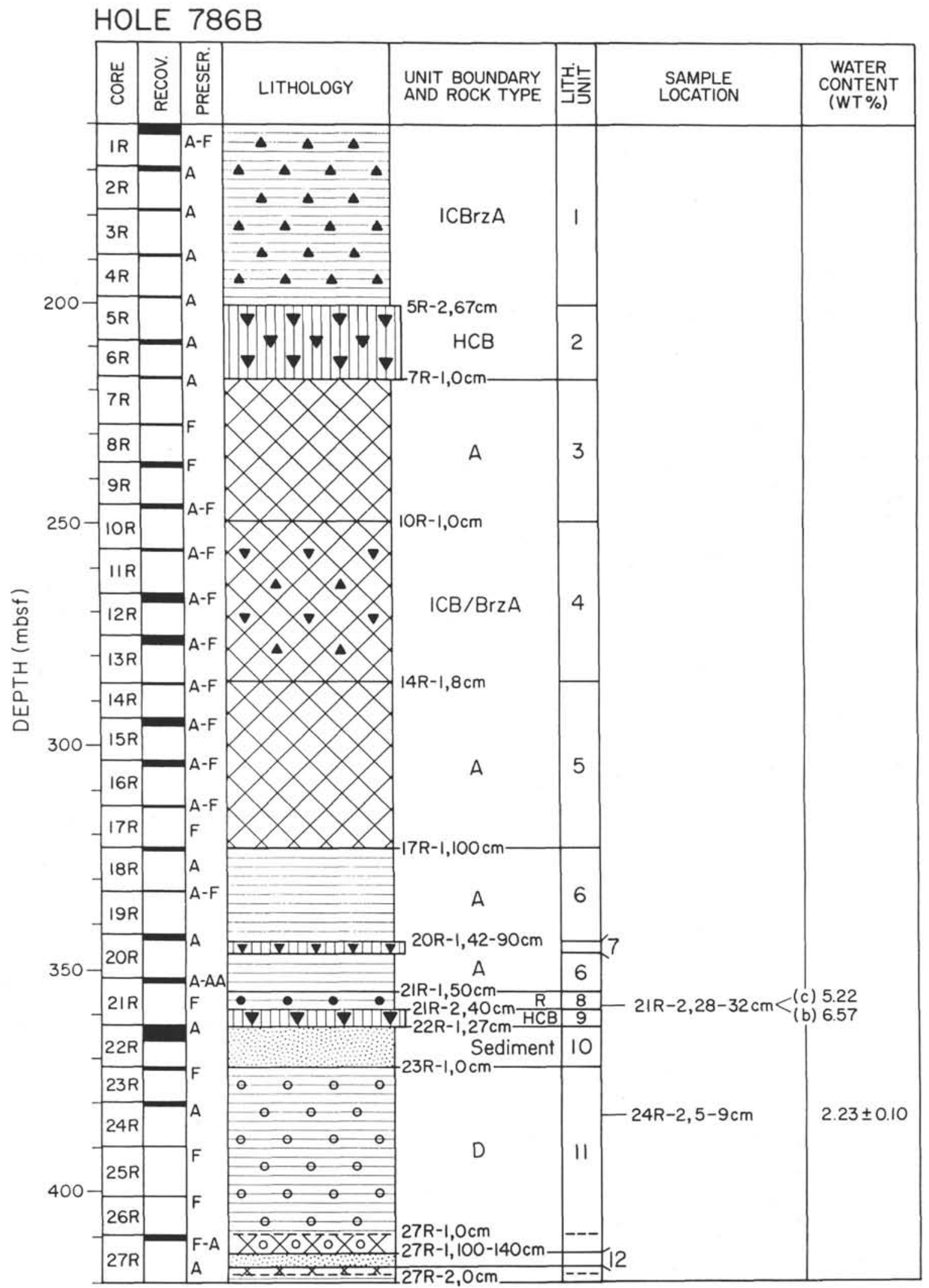

Figure 1. Stratigraphic column with sample horizons and $\mathrm{H}_{2} \mathrm{O}$ contents (adapted from Arculus et al., this volume). 
HOLE 786B (continued)

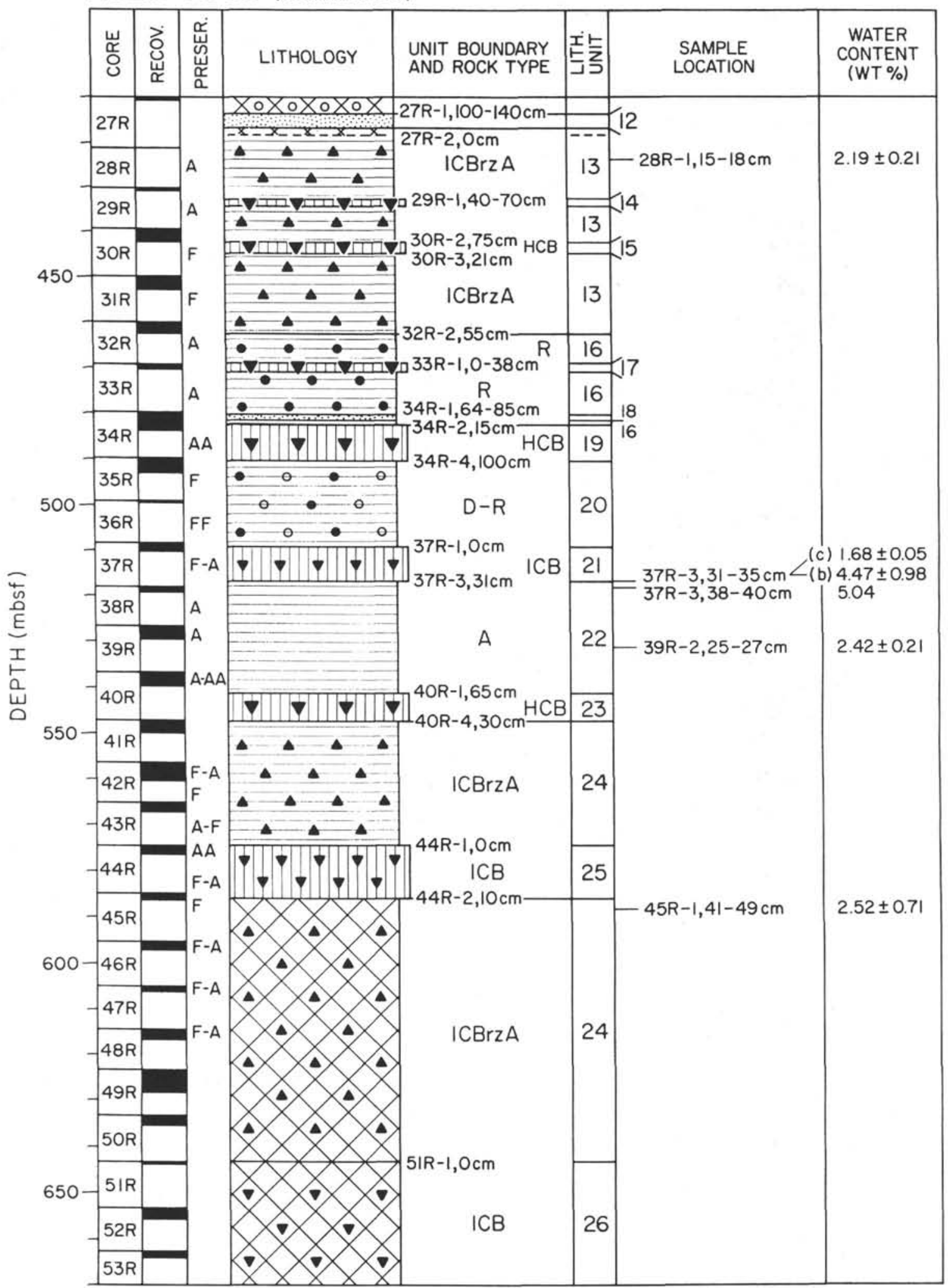

Figure I (continued). 


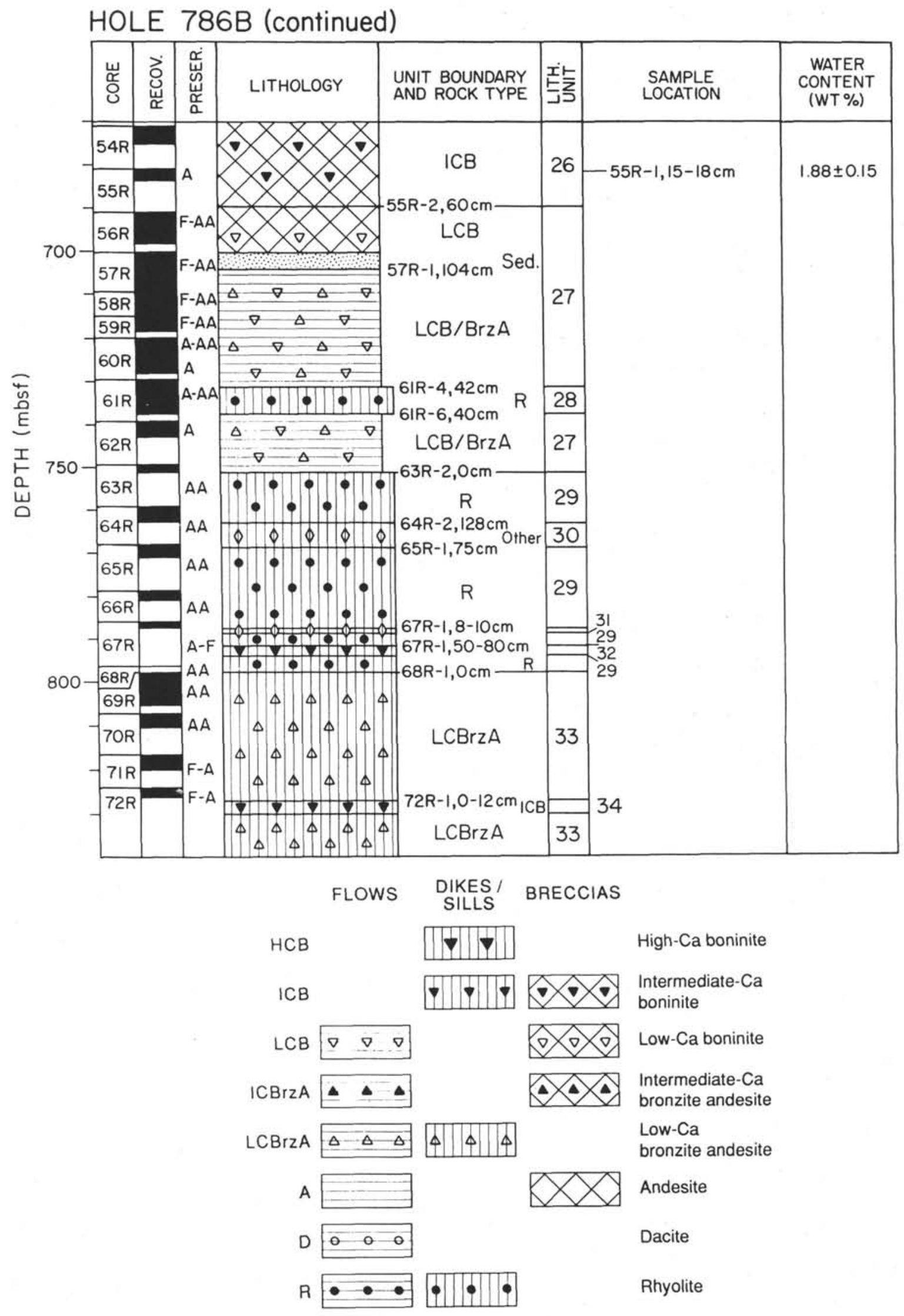

Figure 1 (continued). 


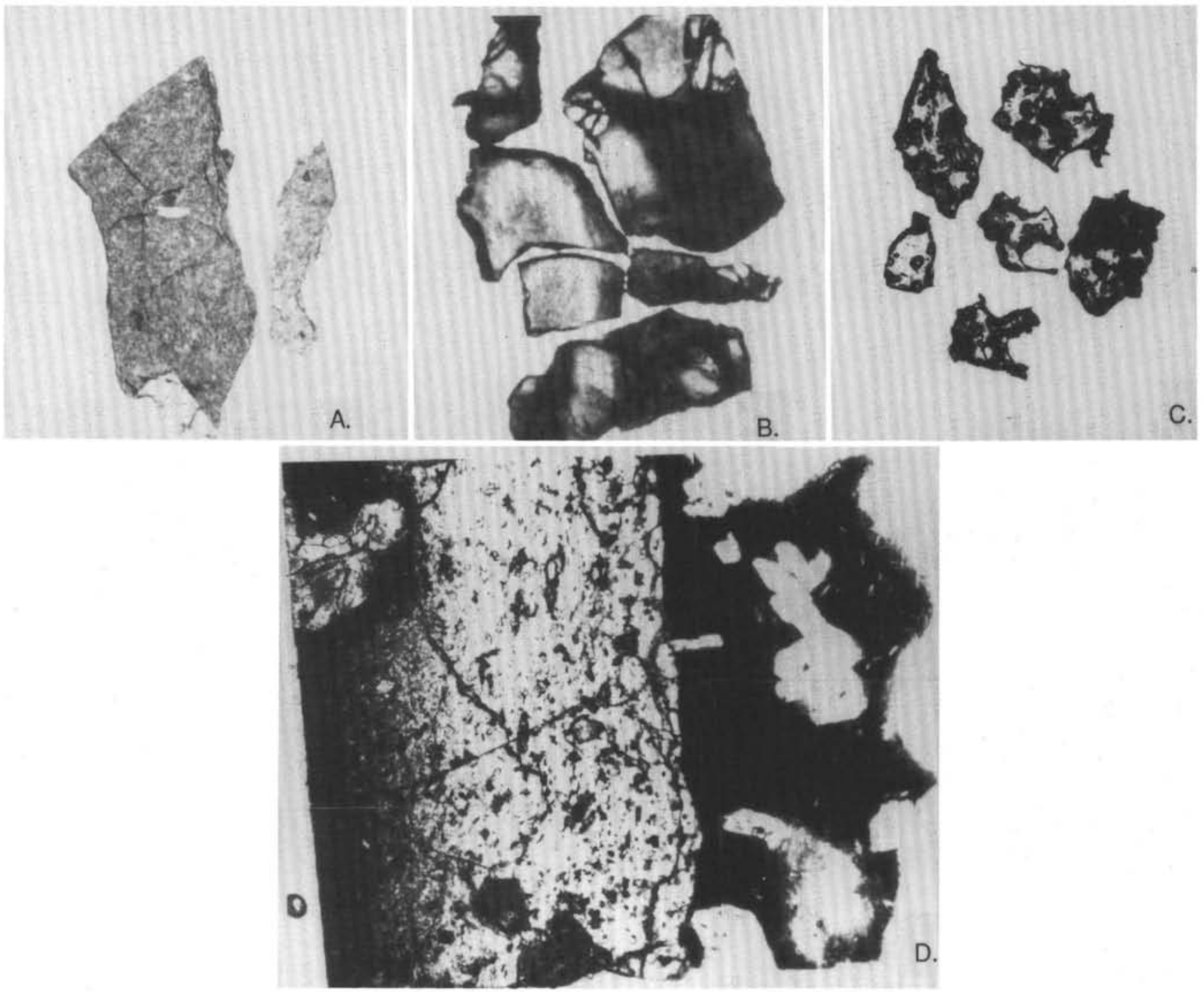

Figure 2. Photomicrographs of polished glass fragments studied by FTIR in this study. A. Sample 125-786B-24R-2, 5-9 cm, showing abundant microlites in the rhyolitic glass. The fragment is $\sim 2.6 \mathrm{~mm}$ long. B. Sample 125-786B-21R-2, 28-32 cm, showing clear rhyolite glass and brown, perhaps perlitic glass. Same scale as (A). C. Sample 125-786A-14X-CC, showing fresh vesicular boninitic glass. Same scale as (A). D. Sample 125-786A-37R-3, 31-35 cm, showing clear, nonvesicular boninitic glass chilled against brown (opaque in such a thick section) glass of intermediate composition. The fragment is $4.7 \mathrm{~mm}$ wide, perpendicular to the chilled margin.

\section{ANALYTICAL TECHNIQUES}

$\mathrm{H}_{2} \mathrm{O}$ and $\mathrm{CO}_{2}$ concentrations were determined on doubly polished thin sections following the FTIR techniques of Newman et al. (1986) and Dixon et al. (1988). However, we encountered two difficulties when applying this technique:

1. Because of the nature of these samples, we generally were not able to analyze entirely crystal-free glass, except for Samples 125786B-21R-2, 28-32 cm, 125-786A-13X-CC, and 125-786A-14XCC. Small percentages of crystals rapidly scatter and diffract significant proportions of light, and the integrated crystal content along the light path attenuates the transmitted light that reaches the detector. To give an impression of the crystal content, we present photomicrographs of the analyzed glasses in Figure 2. Glasses were placed over pinhole apertures of $35,70,200$, and $370 \mu \mathrm{m}$ in diameter, exposing relatively crystal-free glass to the incident beam. Up to seven analyses of various regions of each glass were averaged and are reported in Table 1. Because the microlites are presumably volatile-free, all of the results presented here must be considered minimum values.

2. The FTIR technique must be calibrated for $\mathrm{H}_{2} \mathrm{O}$ and $\mathrm{CO}_{2}$ for each glass composition. The formula used for calculating concentrations from absolute absorbance is as follows:

$$
C=\frac{A \times M W}{\rho \times d \times \varepsilon}
$$

where $C=$ concentration, $A=$ absorbance, $M W=$ molecular weight of the reported analyte, $\rho=$ density in grams/liter $(\mathrm{g} / \mathrm{L}), d=$ thickness in centimeters, and $\varepsilon=$ molar absorptivity. This calibration has been carried out for high-silica rhyolitic $\left(\mathrm{H}_{2} \mathrm{O}\right.$-Newman et al., 1986, and Dobson et al., 1989; $\mathrm{CO}_{2}$ - Blank et al., 1989) and basaltic compositions $\left(\mathrm{H}_{2} \mathrm{O}\right.$ - see Dixon et al., 1988, and Dobson, unpubl. data; $\mathrm{CO}_{2}$-Fine and Stolper, 1986; see Table 2 for the molar absorptivities used in this study). However, most of the glasses studied here are intermediate in composition and therefore the appropriate calibra- 
Table 1. Infrared absorbance data.

\begin{tabular}{|c|c|c|c|c|c|}
\hline Sample & $r^{n}(\mathrm{~g} / \mathrm{L})$ & $\begin{array}{c}\text { Absorption band } \\
(3550) / \mathrm{cm}\end{array}$ & $\begin{array}{c}\text { Absorption band } \\
(5200) / \mathrm{cm}\end{array}$ & $\begin{array}{l}\text { Absorption band } \\
(4500) / \mathrm{cm}\end{array}$ & $\begin{array}{c}\text { Calibration } \\
\text { used }^{b}\end{array}$ \\
\hline \multicolumn{6}{|l|}{$125-786 \mathrm{~A}-$} \\
\hline $13 \mathrm{X}-\mathrm{CC}$ & 2800 & $139.40 \pm 0.28$ & 0.44 & 1.14 . & $(b 3+b 45) / 2$ \\
\hline $14 \mathrm{X}-\mathrm{CC}$ & 2800 & $138.00 \pm 0.57$ & 0.40 & 1.41 & $(b 3+b 45) / 2$ \\
\hline \multicolumn{6}{|l|}{$125-786 \mathrm{~B}-$} \\
\hline${ }^{\prime} 21 R-2,28-32$ & 2350 & Off scale & 8.76 & 2.35 & r45 \\
\hline $21 \mathrm{R}-2,28-32$ & 2350 & Off scale & 11.76 & 2.20 & $\mathrm{r} 45$ \\
\hline $24 \mathrm{R}-2,5-9$ & 2350 & $189.29 \pm 8.11$ & 4.36 & 1.71 & r3 \\
\hline $28 \mathrm{R}-1,15-18$ & 2500 & $210.83 \pm 17.0$ & 3.33 & 1.33 & $(\mathrm{r} 3+\mathrm{r} 45) / 2$ \\
\hline${ }^{3} 7 \mathrm{R}-3,31-35$ & 2500 & $478.19 \pm 45.37$ & $6.48 \pm 0.73$ & $2.11 \pm 0.29$ & $(\mathrm{r} 3+\mathrm{r} 45) / 2$ \\
\hline${ }^{\mathrm{e}} 37 \mathrm{R}-3,31-35$ & 2800 & $164.71 \pm 4.91$ & & & b3 \\
\hline $37 \mathrm{R}-3,38-40$ & 2500 & 493.75 & 9.75 & 1.19 & $(r 3+r 45) / 2$ \\
\hline $39 \mathrm{R}-2,25-27$ & 2500 & $245.43 \pm 6.87$ & 3.13 & 2.09 & $(r 3+r 45) / 2$ \\
\hline $45 R-1,41-49$ & 2500 & 267.69 & 3.45 & 1.15 & $(r 3+r 45) / 2$ \\
\hline $55 \mathrm{R}-1,15-18$ & 2350 & 163.16 & 2.61 & 1.20 & $(\mathrm{r} 3+\mathrm{r} 45) / 2$ \\
\hline
\end{tabular}

tion factors are not yet known. The estimated concentrations are listed in Table 3. We also report raw absorbance data together with the calibration factors used for individual samples (Tables 1 and 2), because the uncertainties in the latter may require recalculation of the concentrations when the molar absorptivities are determined for these compositions.

Microprobe analyses were performed for some of the same polished fragments as used for FTIR and are also given in Table 3. The instrument, a JEOL 733 Superprobe fitted with 5 wavelength spectrometers, was operated at $15 \mathrm{KeV}$ using a 10 -nA current and defocused spot of $10-\mu \mathrm{m}$ diameter rastered over a $20-\times 20-\mu \mathrm{m}$ square. To minimize the effect of alkali migration during the analysis, sodium and potassium were measured first. The data were corrected using a modified ZAF correction (program CITZAF; Armstrong, 1988). The values reported in Table 3 represent the average of four to eight analyses per sample.

\section{RESULTS AND DISCUSSION}

The Izu-Bonin forearc glasses from Holes 786A and 786B contain no significant $\mathrm{CO}_{2}$ but are $\mathrm{H}_{2} \mathrm{O}$-rich. $\mathrm{CO}_{2}$ absorbances are below detection, indicating $\mathrm{CO}_{2}$ concentrations of less than $50 \mathrm{ppm}$ in all samples and less than 30 to $40 \mathrm{ppm}$ in most samples (depending on

Table 2. Molar absorptivities.

\begin{tabular}{ccccc}
\hline & & \multicolumn{3}{c}{ Molar absorptivity (L/mol-cm) } \\
\cline { 3 - 5 } Band $\left(\mathrm{cm}^{-1}\right)$ & Species & Rhyolite & Boninite & Basalt \\
\hline 5200 & $\mathrm{H}_{2} \mathrm{O}$ & ${ }^{\mathrm{a}} 1.61 \pm 0.05$ & ${ }^{\mathrm{b}} 0.82$ & - \\
4500 & $\mathrm{OH}$ & ${ }^{\mathrm{a}} 1.73 \pm 0.02$ & ${ }^{\mathrm{b}} 0.67$ & - \\
${ }^{\mathrm{c}} 3550$ & $\mathrm{OH}$ & ${ }^{\mathrm{d}} 89 \pm 2$ & - & - \\
& $\mathrm{H}_{2} \mathrm{O}$ & ${ }^{\mathrm{a}} 56 \pm 4$ & - & - \\
& Total $\mathrm{H}_{2} \mathrm{O}$ & - & - & ${ }^{\mathrm{e}} 63 \pm 5$ \\
& & & &
\end{tabular}

aNewman et al. (1986)

${ }^{b}$ Dobson (unpubl, data).

${ }^{c}$ Because there is a different molar absorptivity for this band for each $\mathrm{H}$-bearing species in rhyolite, the ratio of the species must be known independently (e.g., from the 5200- and $4500-\mathrm{cm}^{-1}$ bands) in order to use results from the $3550-\mathrm{cm}^{-1}$ band. A reasonable estimate can usually be made based on the general level of the total $\mathrm{H}_{2} \mathrm{O}$ content. however, since the ratio of the species varies regularly with $\mathrm{H}_{2} \mathrm{O}$ content (Silver et al., 1990).

'Dobson et al. (1989).

'Dixon et al. (1988). the quality of the spectrum and thickness of the sample; Table 1). $\mathrm{H}_{2} \mathrm{O}$ concentrations were calculated using several methods, depending on the major element composition of the glass. The absorption bands used from the spectra included the $3550-\mathrm{cm}^{-1}$ band (for total $\mathrm{H}_{2} \mathrm{O}$ ), the $4500-\mathrm{cm}^{-1}$ band (for $\mathrm{OH}$ groups), and the $5200-\mathrm{cm}^{-1}$ band (for molecular $\mathrm{H}_{2} \mathrm{O}$ ). For rhyolites and dacites, calculations were done by averaging concentrations obtained from the $3550-\mathrm{cm}^{-1}$ band and the summed concentrations from the 4500 - and $5200-\mathrm{cm}^{-1}$ bands, respectively, using molar absorptivities for rhyolites (Table 2). In cases where the absorbance for the $3550-\mathrm{cm}^{-1}$ band was off the scale, the concentration reported in Table 3 is that calculated from summing the concentrations from the $5200-$ and $4500-\mathrm{cm}^{-1}$ bands. For the more primitive glass compositions from the boninite samples, basaltic and boninitic molar absorptivities were used (Table 2). The resulting values are presented in Table 3. Reported errors reflect the current uncertainties in calibration factors, not the reproducibility of the measured absorbances, which is $\pm 10 \%$.

Boninitic glass from Samples 125-786A-13X-CC, 125-786A$14 \mathrm{X}-\mathrm{CC}$, and $125-786 \mathrm{~B}-37 \mathrm{R}-3,31-35 \mathrm{~cm}$ (clear), have $\mathrm{H}_{2} \mathrm{O}$ contents of 1.4 to $1.7 \mathrm{wt} \%$. Dacitic and rhyolitic glasses fall into two groups: one with high $\mathrm{H}_{2} \mathrm{O}$ contents between 4.5 and $6.5 \mathrm{wt} \%$ and one with low $\mathrm{H}_{2} \mathrm{O}$ contents between 1.9 and 2.5 wt \%

Major element compositions obtained by electron microscope analysis are presented in Table 3. Assuming that all iron is $\mathrm{Fe}^{2+}$, the analyses have low totals, except for the boninite glasses, which have sums above $99 \%$. When the $\mathrm{H}_{2} \mathrm{O}$ contents are added to the sums of anhydrous oxides, assuming $\mathrm{Fe}^{2+} / \mathrm{Fe}^{3+}=0.75$, the totals are between 97.6 and 99.9 $\mathrm{wt} \%$. If molar absorptivities for intermediate glass compositions are intermediate between rhyolite and boninite/basalt values (Table 2), all $\mathrm{H}_{2} \mathrm{O}$ contents in these samples would actually be higher (see earlier equation) than those listed in Table 3 . The change would be less than $50 \%$ of the amount of $\mathrm{H}_{2} \mathrm{O}$ present.

The $\mathrm{H}_{2} \mathrm{O}$ contents correlate roughly with other major element concentrations (Fig. 3), except for the two dacitic glasses with high $\mathrm{H}_{2} \mathrm{O}$ contents, Samples $125-786 \mathrm{~B}-21 \mathrm{R}-2,28-32 \mathrm{~cm}$, and $125-786 \mathrm{~B}-$ $37 \mathrm{R}-3,31-35 \mathrm{~cm}$ (brown). $\mathrm{H}_{2} \mathrm{O}$ contents of the low- $\mathrm{H}_{2} \mathrm{O}$ samples fall along a single, positive, correlation trend with $\mathrm{Na}_{2} \mathrm{O}$, as shown in Figure 3B. The two dacites with high $\mathrm{H}_{2} \mathrm{O}$ concentrations fall off this trend on a line of similar slope. Similar relationships exist for most other elements and $\mathrm{H}_{2} \mathrm{O}$. Up to four groups can be distinguished in Figure 3, most clearly seen on the plot of $\mathrm{H}_{2} \mathrm{O}$ vs. $\mathrm{SiO}_{2}$ (Fig. 3C): (1) the boninites with the highest $\mathrm{MgO}$ and lowest $\mathrm{SiO}_{2}$ and $\mathrm{H}_{2} \mathrm{O}(\sim 1.5$ wt \%); (2) dacitic glasses with intermediate $\mathrm{SiO}_{2}$ and $\mathrm{H}_{2} \mathrm{O}$ contents of 2-2.5 wt\%; (3) rhyolitic glasses with intermediate $\mathrm{H}_{2} \mathrm{O}$ contents (1.9-2.3 wt\%) and high $\mathrm{SiO}_{2}$; and (4) dacitic-rhyolitic glasses with high $\mathrm{H}_{2} \mathrm{O}$ contents (4.5-6.5 wt\%) and high $\mathrm{SiO}_{2}$. 

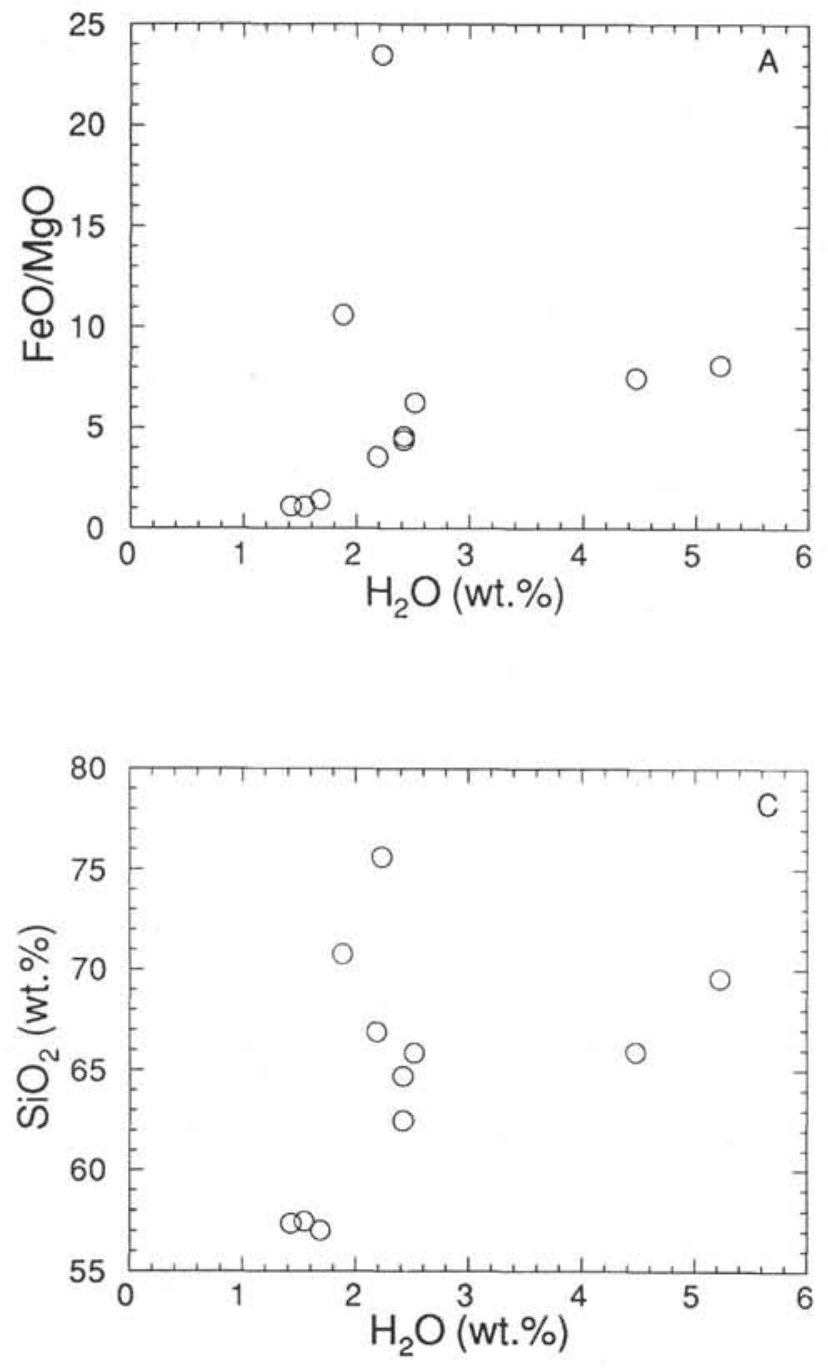

Figure 3. $\mathrm{H}_{2} \mathrm{O}$ variation diagrams for glass compositions.

\section{Effects of Alteration}

The high- $\mathrm{H}_{2} \mathrm{O}$ group raises the problem of whether alteration was a mechanism for producing high $\mathrm{H}_{2} \mathrm{O}$ contents. One of the high- $\mathrm{H}_{2} \mathrm{O}$ samples is Sample 125-786B-21 R-2, 28-32 cm, shown in Figure 2B, which gave two different $\mathrm{H}_{2} \mathrm{O}$ contents for glass of different color. Comparing values for yellow, perhaps perlitically altered, glass with fresh clear glass, one can see that alteration does indeed increase $\mathrm{H}_{2} \mathrm{O}$ contents (yellow $=6.57 \mathrm{wt} \%$ vs. clear $=5.22 \mathrm{wt} \%$ ). However, even the lower concentration is high and must be explained, probably also the result of alteration. The other sample in the fourth group is the brown glass in Sample 125-786B-37R-3, 31-35 cm. Van der Laan et al. (this volume) have found secondary actinolitic amphibole in Sample 125-786B-35R-2, 122-126 cm, clearly indicating that alteration has significantly modified this part of the core. Juxtaposed against this brown, "altered" dacitic glass are glassy margins, $2-3 \mathrm{~cm}$ wide, of boninitic glass (Sample 125-786B-37R-3, 31-35 cm [clear]) containing $1.7 \mathrm{wt} \% \mathrm{H}_{2} \mathrm{O}$. The boninitic glass is from an intermediate$\mathrm{Ca}$ boninite sill that is most likely co-genetic with other dikes/sills dated at 34-35 Ma (Mitchell et al., this volume). Emplacement of this sill is likely to have introduced secondary water in the dacite glass at the very contact. A similar explanation applies to Sample 125-786B$21 \mathrm{R}-1,28-32 \mathrm{~cm}$, which is derived from the contact with a high-Ca boninite dike. For these reasons we consider the high $\mathrm{H}_{2} \mathrm{O}$ contents
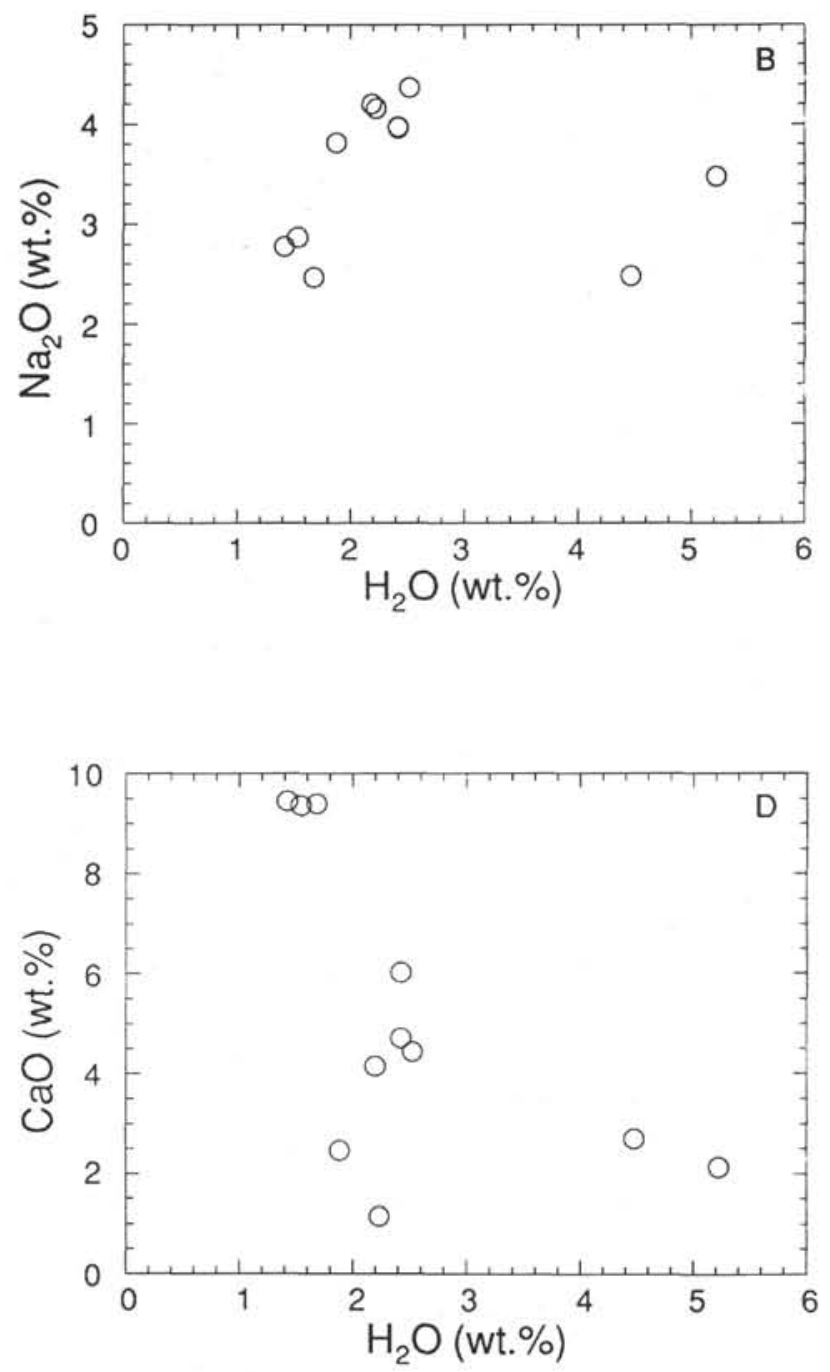

in these samples not to be juvenile. A stable isotope study could elucidate its origin.

\section{Extent of Degassing}

Figure $3 \mathrm{~B}, \mathrm{H}_{2} \mathrm{O}$ vs. $\mathrm{Na}_{2} \mathrm{O}$, shows the most significant correlation for the other three groups $(r=0.89)$. The rhyolitic samples, 125-786B24R-2, 5-9 cm, and 125-786B-55R-1, 15-18 cm, do not have higher $\mathrm{H}_{2} \mathrm{O}$ contents than the dacitic ones, although that would be expected if fractional crystallization were the only process controlling the variation in chemistry of these samples. It seems reasonable that the maximum $\mathrm{H}_{2} \mathrm{O}$ content is controlled by the solubility of $\mathrm{H}_{2} \mathrm{O}$ in the melts at their depths of emplacement and that the rhyolitic and dacitic samples, which are all flows, were emplaced within the same depth range, 3 to $6 \mathrm{~km}$ below the sea surface, assuming $10 \mathrm{~m}$ of seawater for 1 bar of pressure (based on the solubility of $\mathrm{H}_{2} \mathrm{O}$ in rhyolitic melts determined by Silver et al., 1990). Therefore, assuming that the melts were in equilibrium at the depth of emplacement, either the magmas were able to degas any excess $\mathrm{H}_{2} \mathrm{O}$ they contained or they were undersaturated with respect to dissolved $\mathrm{H}_{2} \mathrm{O}$ during melting and ascent. If boninitic glasses have water solubilities similar to those of basalts, then the forearc boninites would have been exactly saturated with respect to $\mathrm{H}_{2} \mathrm{O}$ at ocean depths of $\sim 3000 \mathrm{~m}$ (Hamilton et al., 1964; Dudas, 1983). At greater depths, 
Table 3. Major element glass analyses of samples from Holes 786A and 786B.

\begin{tabular}{|c|c|c|c|c|c|c|c|c|c|}
\hline Hole & $786 \mathrm{~A}$ & $786 \mathrm{~A}$ & $786 \mathrm{~B}$ & $786 \mathrm{~B}$ & $786 \mathrm{~B}$ & $786 \mathrm{~B}$ & $786 \mathrm{~B}$ & $786 \mathrm{~B}$ & $786 \mathrm{~B}$ \\
\hline Core, section & $13 \mathrm{X}-\mathrm{CC}$ & $14 \mathrm{X}-\mathrm{CC}$ & 21R-2 & $21 R-2$ & $21 \mathrm{R}-2$ & 24R-2 & $28 \mathrm{R}-1$ & $37 \mathrm{R}-3$ & $37 R-3$ \\
\hline Interval $(\mathrm{cm})$ & & & $28-32$ & $28-32^{a}$ & $28-32^{b}$ & $5-9$ & $15-18$ & $31-35^{b}$ & $31-35^{a}$ \\
\hline Chem. type & 3 & 3 & 8 & 8 & 8 & 7 & 4 & 7 & 2 \\
\hline $\mathrm{SiO}_{2}$ & $57.39 \pm 0.21$ & $57.49 \pm 0.21$ & $69.57 \pm 1.01$ & & & $75.63 \pm 1.09$ & $66.92 \pm 0.90$ & $65.92 \pm 0.53$ & $57.04 \pm 0.30$ \\
\hline $\mathrm{Al}_{2} \mathrm{O}_{3}$ & $15.67 \pm 0.02$ & $15.61 \pm 0.01$ & $12.03 \pm 0.20$ & & & $10.47 \pm 0.40$ & $13.24 \pm 1.47$ & $11.65 \pm 0.25$ & $15.41 \pm 0.07$ \\
\hline $\mathrm{TiO}_{2}$ & $0.26 \pm 0.06$ & $0.27 \pm 0.02$ & $0.15 \pm 0.10$ & & & $0.30 \pm 0.14$ & $0.22 \pm 0.11$ & $0.33 \pm 0.03$ & $0.42 \pm 0.00$ \\
\hline $\mathrm{MgO}$ & $5.72 \pm 0.05$ & $5.73 \pm 0.07$ & $0.35 \pm 0.06$ & & & $0.08 \pm 0.05$ & $1.47 \pm 1.06$ & $0.79 \pm 0.14$ & $5.04 \pm 0.04$ \\
\hline $\mathrm{FeO}$ & $6.32 \pm 0.04$ & $6.20 \pm 0.26$ & $2.85 \pm 0.15$ & & & $1.88 \pm 0.54$ & $5.25 \pm 0.75$ & $5.94 \pm 0.54$ & $7.18 \pm 0.07$ \\
\hline $\mathrm{CaO}$ & $9.46 \pm 0.03$ & $9.37 \pm 0.05$ & $2.13 \pm 0.10$ & & & $1.15 \pm 0.32$ & $4.16 \pm 0.73$ & $2.70 \pm 0.25$ & $9.41 \pm 0.07$ \\
\hline $\mathrm{Na}_{2} \mathrm{O}$ & $2.78 \pm 0.03$ & $2.87 \pm 0.04$ & $3.48 \pm 0.06$ & & & $4.16 \pm 0.36$ & $4.21 \pm 0.34$ & $2.48 \pm 0.19$ & $2.47 \pm 0.03$ \\
\hline $\mathrm{K}_{2} \mathrm{O}$ & $0.23 \pm 0.05$ & $0.25 \pm 0.03$ & $2.32 \pm 0.87$ & & & $1.83 \pm 0.52$ & $0.74 \pm 0.10$ & $2.84 \pm 0.12$ & $0.23 \pm 0.01$ \\
\hline $\mathrm{MnO}$ & $0.11 \pm 0.17$ & $0.12 \pm 0.03$ & $0.08 \pm 0.06$ & & & $0.01 \pm 0.02$ & $0.09 \pm 0.06$ & $0.08 \pm 0.05$ & $0.14 \pm 0.03$ \\
\hline $\mathrm{Cr}_{2} \mathrm{O}_{3}$ & $0.04 \pm 0.07$ & $0.03 \pm 0.03$ & $0.00 \pm 0.00$ & & & $0.04 \pm 0.03$ & $0.02 \pm 0.02$ & $0.01 \pm 0.01$ & $0.02 \pm 0.02$ \\
\hline $\mathrm{H}_{2} \mathrm{O}^{3}$ & $1.43 \pm 0.01$ & $1.54 \pm 0.18$ & 5.22 & 5.22 & 6.57 & $2.23 \pm 0.10$ & $2.19 \pm 0.21$ & $4.47 \pm 0.98$ & $1.68 \pm 0.05$ \\
\hline Total & $99.41 \pm 0.07$ & $99.49 \pm 0.38$ & $98.21 \pm 0.47$ & & & $97.78 \pm 1.13$ & $98.50 \pm 0.87$ & $97.21 \pm 0.37$ & $99.05 \pm 0.39$ \\
\hline Total (assuming $\mathrm{Fe}^{2+} / \mathrm{Fe}^{3+}=0.75$ ) & $99.80 \pm 0.07$ & $99.87 \pm 0.38$ & $98.39 \pm 0.47$ & & & $97.90 \pm 1.13$ & $98.84 \pm 0.87$ & $97.59 \pm 0.37$ & $99.50 \pm 0.39$ \\
\hline
\end{tabular}

Note: Reported errors are $1 \sigma$ standard deviation of multiple analyses.

${ }^{\text {a Clear glass. }}$

${ }^{\text {b Brown glass. }}$

these glasses would be undersaturated. The vesicles observed in Sample 125-786A-14X-CC suggest that this boninite was actively degassing at the time of eruption, and therefore it was probably very close to saturation with respect to $\mathrm{H}_{2} \mathrm{O}$. The water depth corresponding to the pressure for $\mathrm{H}_{2} \mathrm{O}$ saturation for this sample is $3100 \mathrm{~m}$. This is the current depth to the ocean floor, and therefore, no significant tectonic movement has occurred since its emplacement. Thus all of the presumably unaltered glasses are appropriately degassed for their depths of emplacement. No net vertical tectonic movement has occurred in the last $40 \mathrm{Ma}$ in this region-uplift and subsidence since the Eocene have been in balance.

\section{Comparison with Other Oceanic Basalts}

Glass samples for which we have both major element and $\mathrm{H}_{2} \mathrm{O}$ contents include both boninites and dacites to rhyolites. The glasses in the boninites actually contain much less $\mathrm{MgO}$ than the whole rocks, suggesting that significant olivine and pyroxene crystallization occurred just prior to quenching. These glasses have $\mathrm{H}_{2} \mathrm{O}$ contents (1.4 to $1.7 \mathrm{wt} \%$ ) that are very high compared with normal mid-ocean ridge basalts (N-MORB: 0.1 to $0.4 \mathrm{wt} \%$; Fine and Stolper, 1986), enriched mid-ocean ridge basalts (E-MORB: 0.1 to $0.5 \mathrm{wt} \%$; Dixon et al., 1988), or ocean island basalts (OIB: 0.1 to $0.9 \mathrm{wt} \%$; Dixon et al., 1991). However, the $\mathrm{H}_{2} \mathrm{O}$ concentrations in the boninites are comparable to those found in backarc basin basalts (BABB: 0.2 to 2.2 wt\%), including the Mariana Trough, Lau Basin, and Sumisu Rift (Garcia et al., 1979; Poreda, 1985; Newman, 1989, 1990; Hochstaedter et al., 1990). The Sumisu Rift BABBs, which are just behind the Izu-Bonin Arc from the location of Holes 786A and 786B, also contain no $\mathrm{CO}_{2}$, whereas there is significant $\mathrm{CO}_{2}$ in some of the $\mathrm{Lau}$ Basin and Mariana Trough BABBs.

\section{SUMMARY}

Volcanic glasses from Holes 786 A and 786B include boninites containing 1.4 to $1.7 \mathrm{wt} \% \mathrm{H}_{2} \mathrm{O}$ and rocks of dacitic to rhyolitic compositions containing 2 to $6 \mathrm{wt} \% \mathrm{H}_{2} \mathrm{O}$. No significant $\mathrm{CO}_{2}$ was observed in any of the glasses. Alteration, presumably by interaction with seawater percolating through the volcanic pile and aided by the heat introduced by emplacement of dikes/sills, has significantly increased the $\mathrm{H}_{2} \mathrm{O}$ contents of at least some of the glasses. The others contain the amount of $\mathrm{H}_{2} \mathrm{O}$ expected for their depths of collection, which therefore probably were their depths of eruption. This depth is 3 to $6 \mathrm{~km}$ below the sea surface. No net vertical movement has occurred since the Eocene emplacement of these rocks.

\section{ACKNOWLEDGMENT}

Support for this work included some funds from NSF grant EAR-8811406.

\section{REFERENCES}

Armstrong, J. T., 1988. Quantitative analysis of silicate and oxide materials: comparison of Monte Carlo, ZAF and $(\alpha z)$ procedures. In Newbury, D. E. (Ed.), Microbeam Analyses: San Francisco (San Francisco Press), 239-246.

Blank, J. G., Stolper, E. M., Sheng, J., and Epstein, S., 1989. The solubility of $\mathrm{CO}_{2}$ in rhyolitic melt at pressures to 1500 bars. Geol. Soc. Am. Abstr. Programs, A157.

Cameron, W. E., Nisbet, E. G., and Dietrich, V. J., 1979. Boninites, komatiites and ophiolitic basalts. Nature, 280:550-553.

Dixon, J. E., Clague, D. A., and Stolper, E. M., 1991. Degassing history of water, sulfur, and carbon in submarine lavas from Kilauea Volcano, Hawaii. J. Geol., 99:371-394.

Dixon, J. E., Stolper, E., and Delaney, J. R., 1988. Infrared spectroscopic measurements of $\mathrm{CO}_{2}$ and $\mathrm{H}_{2} \mathrm{O}$ in Juan de Fuca Ridge basaltic glasses. Earth Planet. Sci. Lett., 90:87-104.

Dobson, P. F., Epstein, S., and Stolper, E. M., 1989. Hydrogen isotope fractionation between coexisting vapor and silicate glasses and melts at low pressure. Geochim. Cosmochim. Acta, 53:2723-2730.

Dobson, P. F., and O'Neil, J. R., 1987. Stable isotope compositions and $\mathrm{H}_{2} \mathrm{O}$ contents of boninite series rocks from Chichi-Jima, Bonin Islands, Japan. Earth Planet. Sci. Lett., 82:75-86.

Dudas, F. O., 1983. The effect of volatile content on the vesiculation of submarine basalts. Econ. Geol. Monogr., 5:134-141.

Fine, G., and Stolper, E., 1986. Dissolved carbon dioxide in basaltic glasses: concentrations and speciation. Earth Planet. Sci. Lett., 76:263-278.

Garcia, M. O., Liu, N.W.K., and Muenow, D. W., 1979. Volatiles in submarine volcanic rocks from the Mariana island arc and trough. Geochim. Cosmochim. Acta, 43:305-312.

Hamilton, D. J., Burnham, C. W., and Osborn, E. F., 1964. The solubility of $\mathrm{H}_{2} \mathrm{O}$ and the effects of oxygen fugacity and $\mathrm{H}_{2} \mathrm{O}$ contents on crystallization in mafic magmas. J. Petrol., 5:21-39.

Hochstaedter, A. G., Gill, J. B., Kusakabe, M., Newman, S., Pringle, M., Morris, J. D., Langmuir, C. H., Taylor, B., and Fryer, P., 1990. Major and trace element, isotope, and volatile geochemistry of lavas from the Sumisu Rift: an incipient back-arc basin. Earth Planet. Sci. Lett., 100:179-194.

Kuroda, N., Shiraki, K., and Urano, H., 1978. Boninites as a possible calcalkaline primary magma. Bull. Volcanol., 41:563-575.

Kyser, T. K., Cameron, W. E., and Nisbet, E. G., 1986. Boninite petrogenesis and alteration history: constraints from stable isotope compositions of boninites from Cape Vogel, New Caledonia and Cyprus. Contrib. Mineral. Petrol., 93:222-226.

Newman, S., 1989. Water and carbon dioxide contents in basaltic glasses from the Mariana Trough. Eos, 70:1387. 
Table 3 (continued).

\begin{tabular}{cccc}
\hline $786 \mathrm{~B}$ & $786 \mathrm{~B}$ & $786 \mathrm{~B}$ & $\begin{array}{c}786 \mathrm{~B} \\
37 \mathrm{R}-3\end{array}$ \\
$38-40$ & $25 \mathrm{R}-2$ & $45 \mathrm{R}-1$ & $55 \mathrm{R}-1$ \\
& 7 & $41-49$ & $15-18$ \\
& & 4 & 4 \\
\hline & $64.73 \pm 0.15$ & $65.89 \pm 0.35$ & $70.78 \pm 1.37$ \\
& $12.56 \pm 0.42$ & $14.24 \pm 1.79$ & $12.00 \pm 0.79$ \\
& $0.38 \pm 0.07$ & $0.43 \pm 0.08$ & $0.42 \pm 0.07$ \\
& $1.57 \pm 0.04$ & $0.79 \pm 0.42$ & $0.41 \pm 0.19$ \\
& $6.89 \pm 0.29$ & $4.95 \pm 1.65$ & $4.35 \pm 0.79$ \\
& $4.72 \pm 0.05$ & $4.45 \pm 0.60$ & $2.47 \pm 0.61$ \\
& $3.97 \pm 0.11$ & $4.37 \pm 0.26$ & $3.82 \pm 0.19$ \\
& $0.59 \pm 0.07$ & $0.80 \pm 0.14$ & $1.88 \pm 0.08$ \\
& $0.07 \pm 0.04$ & $0.07 \pm 0.05$ & $0.12 \pm 0.12$ \\
5.04 & $0.03 \pm 0.03$ & $0.02 \pm 0.02$ & $0.09 \pm 0.02$ \\
& $2.42 \pm 0.21$ & $2.52 \pm 0.71$ & $1.88 \pm 0.15$ \\
& $97.96 \pm 0.54$ & $98.53 \pm 0.80$ & $98.22 \pm 0.82$ \\
& $98.40 \pm 0.54$ & $98.84 \pm 0.80$ & $98.50 \pm 0.82$ \\
\hline
\end{tabular}

1990. Water and carbon dioxide contents of back arc basin basalts. V.M. Goldschmidt Conf. Program Abstr., 69. (Abstract)

Newman, S., Stolper, E. M., and Epstein, S., 1986. Measurement of water in rhyolitic glasses: calibration of an infrared spectroscopic technique. Am. Mineral., 71:1527-1541.

Poreda, R. J., 1985. Helium-3 and deuterium in back-arc basalts: Lau Basin and the Mariana Trough. Earth Planet. Sci. Lett., 73:244-254.

Silver, L. A., Ihinger, P. D., and Stolper, E., 1990. The influence of bulk composition on the speciation of water in silicate glasses. Contrib. Mineral. Petrol., 104:142-162.

Date of initial receipt: 1 October 1990

Date of acceptance: 16 July 1991

Ms 125B-140 